\title{
PERENCANAAN STRATEGIC MANAGEMENT SISTEM INFORMASI DENGAN BALANCED SCORECARD PADA TAMAN KANAK-KANAK
}

\author{
Dewi Mustari \\ Program Studi Teknik Informatika, Universitas Indraprasta PGRI \\ Email: mustaridewi@yahoo.com
}

\begin{abstract}
Abstrak
Sistem informasi merupakan sebuah sistem yang memuat segala informasi yang dibutuhkan oleh pengguna yang dalam hal ini yaitu kepala sekolah, guru, dan orang tua siswa.Pengembangan organisasi merupakan pemikiran strategis yang harusdiwujudkan dalam perencanaan strategis pengembangan organisasi terutama pengembangan rencana strategis sistem informasi organisasi. Tujuan dari perencanaan strategis management sistem informasi taman kanak-kanak yang akan diimplementasikan sebagai kebijakan strategis management Taman Kanak - Kanak X dalam menyusun rencana strategi dan kondisi bisnis yang diharapkan oleh Taman kanak - kanak X untuk kedepannya. Sehingga memiliki daya saing yang kompetitif dengan taman kanak - kanak pesaingnya. Tujuan dari penelitian ini adalah membuat perencanaan strategis sistem informasi berbasis web dilingkungan internal dan eksternal Taman Kanak - Kanak X dengan menggunakan analisis swot dan Balanced Scorecard. Manfaat dari penelitian ini adalah diharapkan dengan membuat perencanaan strategic management sistem informasi ini bisa menjadi referansi untuk pengembangan sistem informasi di Taman Kanak - Kanak X dan sebagai bahan evaluasi sertapenyempurnaan dari kebijakan-kebijakan yang telah dan akan diambil, khususnya pada perencanaan strategi management sistem informasi sekolah Taman Kanak- kanak X.
\end{abstract}

Kata Kunci: Sistem Informasi, SWOT, Balanced Scorecard

\section{Pendahuluan}

Setiap saat teknologi informasi berkembang dengan begitu cepatnya terutama dalam bidang sistem informasi. Sistem informasi merupakan sebuah sistem yang memuat segalan informasi yang dibutuhkan oleh pengguna yang dalam hal ini yaitu kepala sekolah, guru, orang tua siswa. Lembaga pendidikan mempunyai peran yang sangat penting juga dalam mencetak sumber daya manusia yang berkualitas yang dimulai dari pendidikan yang mendasar yaitu ditingkat taman kanak-kanak. Saat ini taman kanak-kanak merupakan salah satu pendidikan formal yang memfasilitasi tumbuh kembang anak yang menekankan pada aspek kepribadian sehingga pendidikan usia dini harus memiliki sumber daya yang berkualitas. Untuk memberntuk sumber daya manusia yang berkualitas tentunya semua pihak yang terkait di dunia pendidikan baik itu tenaga pengajar ataupun masyarakat harus bekerja sama untuk meningkatkan mutu pendidikan.

Lembaga pendidikan tentunya harus memberikan pelayanan yang terbaik kepada siswa yang khususnya untuk taman kanak-kanak ini lebih ditekankan kepada orang tua siswa.semakin cepat informasi itu diterima oleh orang tua siswa maka akan semakin cepat juga perbaikan mutu pendidikan siswa. Untuk dapat memberikan informasi secara tepat, cepat dan akurat, Lembaga pendidikan memerlukan sebuah sistem informasi terpadu yang berkualitas. Taman kanak- kanak X yang berada di kota Banjar Ciamis, belum begitu paham mengenai teknologi informasi sehingga untuk penerapan sistem informasi masih kurang. Oleh karena itu diperlukan sebuah sistem informasi berbasis web untuk bisa memberikan pelayanan yang lebih baik lagi kedepannya.

Pengembangan organisasi merupakan pemikiran strategis yang harusdiwujudkan dalam perencanaan strategis pengembangan organisasi terutama pengembangan rencana strategis sistem informasi organisasi. Tujuan dari perencanaan strategic management sistem informasi taman kanak-kanak yang akan diimplementasikan sebagai kebijakan strategic management 
Taman Kanak - Kanak X dalam menyusun rencana strategi dan kondisi bisnis yang di harapkan oleh Taman kanak - kanak X untuk kedepannya. Sehingga memiliki daya saing yang kompetitif dengan taman kanak - kanak pesaingnya.

Tujuan dari penelitian ini adalah membuat perencanaan strategic sistem informasi berbasis web dilingkungan internal dan eksternal Taman Kanak - Kanak X dengan menggunakan analisis swot dan Balanced Scorecard. Manfaat dari penelitian ini adalah diharapkan dengan membuat perencanaan strategic management sistem informasi ini bisa menjadi referansi untuk pengembangan sistem informasi di Taman Kanak - Kanak X dan sebagai bahan evaluasi sertapenyempurnaan dari kebijakan-kebijakan yang telah dan akan diambil, khususnya pada perencanaan strategi management sistem informasi sekolah Taman Kanakkanak X.

\section{Tinjauan Pustaka}

Data, informasi dan knowledge pada dasarnya merupakan konsep yang saling berhubungan. Menurut Bergeron (2003), yang dimaksud data, informasi dan knowledge dibedakan sebagai berikut :

1. Data adalah angka atau atribut yang bersifat kuantitas yang berasal dari hasil observasi, eksperimen atau kalkulasi.

2. Informasi adalah data di dalam satu kontektual tertentu merupakan kumpulan data dan terkait dengan penjelasan, interpretasi dan berhubungan dengan materi lainnya mengenai objek, peristiwa atau proses tertentu.

3. Knowledge adalah informasi yang telah diorganisasi, disintesiskan, diringkaskan untuk meningkatkan perngertian, kesadaran atau pemahaman.

Manajemen strategis merupakan rangkaian dua perkataan dari kata "manajemen dan strategi" yang masing-masing memiliki satu terminologi berubah dengan memiliki pengertian tersendiri pula. Menurut Holt (dalam Winardi, 2000) sebagai berikut: "Management is the process of planning, organizing, leading, and controling that encompasses human, material, financial and information resourcess is an organizational envirounment".

Hubungan antara strategi SI, strategi bisnis, dan strategi TI adalah strategi bisnis merumuskan sasaran, arah, dan kebijakan bisnis organisasi. Strategi bisnis menjelaskan arah bisnis yang berjalan. Strategi TI digunakan untuk mendefinisikan pemenuhan kebutuhan organisasi akan sistem dan informasi. Sedangkan strategi SI menentukan aplikasi SI yang dibutuhkan organisasi. Hubungan tersebut dapat dilihat pada gambar 1.

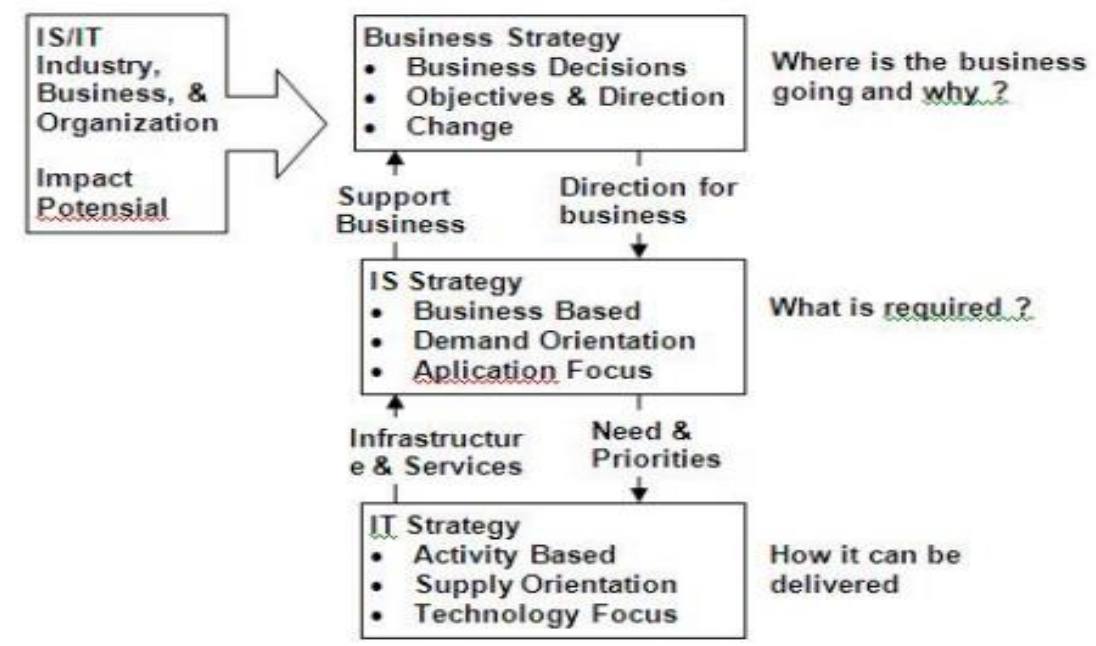

Gambar 1. Hubungan antara Strategi Bisnis, Strategi SI dan Strategi TI

(Sumber: Ward, 2003) 
Perangkat lunak sebagai salah satu komponen TI, yang digunakan berkaitan dengan aktivitas atau Proses Bisnis suatu organisasi disebut aplikasi (Ward, 2003). Portofolio aplikasi sebagai hasil dari perencanaan strategi SI, dapat dikategorikan menjadi empat jenis berdasarkan kontribusinya terhadap bisnis (Gambar 2).

\begin{tabular}{|c|c|}
\hline STRATEGIC & HIGH POTENTIAL \\
\hline $\begin{array}{l}\text { Aplikasi yang sangat } \\
\text { penting untuk } \\
\text { mempertahankan strategi } \\
\text { bisnis masa depan }\end{array}$ & $\begin{array}{l}\text { Aplikasi yang } \\
\text { penting dalam mencapain } \\
\text { keberhasilan di masa } \\
\text { mendatang }\end{array}$ \\
\hline $\begin{array}{l}\text { Application on which the } \\
\text { organization currently } \\
\text { depends for success }\end{array}$ & $\begin{array}{l}\text { Application that are } \\
\text { valuable but not critical to } \\
\text { success }\end{array}$ \\
\hline KEY OPERATIONAL & SUPPORT \\
\hline
\end{tabular}

\section{Gambar 2. Matriks Portofolio Aplikasi}

(Sumber: Ward, 2003)

Menurut Jogiyanto (2005) Analisis SWOT digunakan untuk menilai kekuatan dan kelemahan yang dimiliki oleh sumber daya internal perusahaan serta kesempatan dan tantangan yang berasal dari pihak eksternal perusahaan. Setelah mengetahui SWOT dari perusahaan, selanjutnya adalah melakukan pendefinisian terhadap SWOT matriks. Tujuannya adalah untuk membantu mendapatkan pengertian yang baik dari pilihan yang ada.

Menurut Mind Tools terdapat beberapa tahapan dalam pendefinisian SWOT Matriks, yaitu:

1. Pendefinisian dari SWOT analisis untuk membantu mendefinisikan strength, weakness, opportunities, dan threats dari perusahaan.

2. Mendefinisikan kesimpulan utama dari SWOT analisis dan kemudian didefinisikan atau dikelompokkan kedalam SWOT (internal dan eksternal faktor).

3. Untuk masing-masing kombinasi yang ada dari internal dan eksternal factor, tujuannya adalah untuk membantu pilihan strategi yang terbaik.

a. Strategi SO: Strategi yang digunakan perusahaan dengan memanfaatkan atau mengoptimalkan kekuatan yang dimilikinya untuk memanfaatkan berbagai peluang yang ada.

b. Strategi WO: Strategi yang digunakan perusahaan dengan seoptimal mungkin untuk meminimalisir yang ada di perusahaan untuk memanfaatkan berbagai peluang yang ada.

c. Strategi ST: Strategi yang digunakan perusahaan dengan memanfaatkan kekuatan untuk mengurangi ancaman yang dating ke perusahaan.

d. Strategi WT: Strategi yang digunakan perusahaan untuk mengurangi kelemahan untuk menghindari ancaman yang dating ke perusahaan.

4. Melakukan evaluasi pilihan yang digeneralisasi dan melakukan identifikasi dari benefit yang terbaik dan pencapaian terbaik terhadap visi dan misi dari organisasi.

Menurut Kaplan (1996) Balanced Scorecard tolak ukur financial hanya menyajikan seberapa baik penerapan strategi perusahaan dimasa lampau, sedangkan tolak ukur non financial akan digunakan untuk mengukur keberhasilan yang akan diperoleh perusahaan dimasa mendatang. Keuntungan lain dari penerapan Balanced Scorecard dalam perusahaan adalah terjadinya keseimbangan antara pencapaian tujuan jangka pendek dan jangka panjang dari segi financial dan non financial. Pendefinisian Balances Scorecard ini pada akhirnya akan menghasilkan sebuah Strategy Map. Empat perspektif pada Balanced Scorecard adalah Learning and Growth, Internal Business Processes, Customer Perspective dan Financial Perspective.

1. Learning and Growth

Perspective ini berkaitan dengan Trainning untuk pekerja atau karyawan. Budaya Perusahaan yang berhubungan dengan Improvement pada individu atau Perusahaan 
secara keseluruhan. Learning juga berkaitan dengan "Mentoring dan Tutor"untuk semua komponen yang ada diperusahaan.

2. Internal Business Processes

Perspective ini berkaitan dengan pemahaman manager terkait dengan bagaimana bisnis dijalankan dan produk atau jasa mana yang diminta oleh konsumen disesuaikan dengan misi perusahaan.

3. Customer Perspective

Perspective ini berkaitan dengan filosofi management untuk meningkatkan realisasi Customer Focus dan Customer Satisfaction pada semua bisnis. Pada perspective ini konsumen akan melakukan analisis pada "term and process" yang berkaitan dengan penyediaan barang atau jasa untuk masing-masing kelompok konsumen.

4. Financial Perspective

Pada perspective ini dibutuhkan pencarian data yang "Timely dan Accurate" menjadi prioritas utama sehingga dapat dianalisis oleh manager untuk menyiapkan kebutuhan perusahaan terkait dengan data keuangan.

Terdapat Sembilan tahapan dalam membuat atau menganalisis balanced Scorecard perusahaan yang didefinisikan oleh Balanced Scorecard, yaitu:
1. Assessment
6. Initiative
2. Strategy
7. Automation
3. Objectives
8. Cascade
4. Strategy Map
9. Evaluation
5. Performance Measurement

\section{Metodologi Penelitian}

Metode yang digunakan dalam penelitian ini adalah studi pustaka dari berbagai kasus dalam jurnal yang membahas mengenai bagaimana membuat perencanaan strategic management sistem informasi, dan juga bagaimana memetakannya kedalam strategi management dengan menggunakan Balanced Scorecard pada sebuah institusi / lembaga sehingga menghasilkan analisis deskriptif. Dan pendekatan pada penelitian ini adalah pendekatan secara general empiris berdasarkan pengalaman dan teori-teori yang berkaitan dengan metode perencanaan strategic management sistem informasi dan strategi manajemen dengan menggunakan Balanced Scorecard.

\section{Hasil dan Pembahasan}

\section{Hasil Analisis SWOT}

a. Strength

1) Lokasi Sekolah yang strategis dekat dengan lingkungan masyarakat dan kota.

2) Memiliki SDM berkualitas yang didukung dengan peningkatan kompetensi dari pengajarnya.

3) Memberikan pelayanan yang baik dan memuaskan.

4) Harga yang terjangkau dan murah.

5) Didukung penuh oleh yayasan PGRI.

b. Weaknesses

1) Masih kurangnya sarana dan prasarana untuk mendukung kegiatan belajar mengajar.

2) Kurangnya dukungan teknologi informasi.

3) Adanya tuntutan dari orang tua siswa.

c. Opportunities

1) Banyaknya calon siswa.

2) Antusias calon orang tua siswa untuk memberikan pendidikan usia dini pada anaknya.

3) Pandangan masyarakat terhadap lembaga pendidikan. 
4) Dukungan pemerintah di dunia pendidikan.

d. Threats

1) Minat masyarakat akan TK Negeri.

2) Masih rendahnya minat menyekolahkan anak ke TK.

3) Kurang pengetahuan mengenai pentingnya pendidikan usia dini untuk anak.

4) Tingkat perekonomian masyarakat.

\section{Strategy Management}

Strategi manajemen yang akan diterapkan pada Taman Kanak - Kanak X yaitu dengan menggunakan Tools SWOT yang merupakan hasil dari analisis SWOT matriks sebagai berikut:

Tabel 1. Matriks SWOT

\begin{tabular}{|c|c|c|c|}
\hline \multirow{2}{*}{\multicolumn{2}{|c|}{ Strategy SWOT }} & \multicolumn{2}{|c|}{ Faktor Internal } \\
\hline & & Strength & Weaknesses \\
\hline \multirow[b]{2}{*}{$\begin{array}{c}\text { Faktor } \\
\text { Eksternal }\end{array}$} & Opportunity & $\begin{array}{ll}\text { Strategi SO } \\
& \text { Meningkatkan Jaringan } \\
\circ & \frac{\text { Meningkatkan kualitas SDM }}{\text { Meningkatkan kualitas dan }} \\
\circ & \frac{\text { pelayanan pada masyarakat }}{\text { Memberikan harga yg kompetitif }} \\
\circ & \text { Memal }\end{array}$ & $\begin{array}{l}\frac{\text { Strategi WO }}{\circ} \text { Meningkatkan dukungan } \\
\frac{\text { teknologi informasi }}{\text { Meningkatkan sarana dan }} \\
\text { prasarana }\end{array}$ \\
\hline & Threats & $\begin{array}{ll}\text { Strategi ST } \\
\text { Meningkatkan mutu dan kualitas } \\
\frac{\text { pelayanan pada siswa }}{\circ \text { Meningkatkan kualitas luaran }} \\
\frac{\text { Meningkatkan kualitas kinerja }}{}\end{array}$ & $\begin{array}{l}\frac{\text { Strategi WT }}{\circ} \\
\frac{\text { Meningkatkan kepercayaan }}{\text { masyarakat }} \\
\frac{\text { Meningkatkan dukungan }}{\text { teknologi informsi }}\end{array}$ \\
\hline
\end{tabular}

\section{Hasil Analisis Balanced Scorecard}

Berikut ini adalah analisis yang terkait dengan pembuatan Balanced Scorecard adalah:

a. Assessment

Berdasarkan visi dan misi yang diterapkan pada Taman Kanak Kanak X yang berada di Pataruman Kota Banjar, disimpulkan bahwa dalam menjalankan kegiatan sehari-hari, Taman Kanak-kanak $\mathrm{X}$ berusaha untuk menjadi tempat pendidikan yang selalu mengedepankan kualitas dari pengajar dan siswanya, sebagai upaya untuk menghadapi tantangan di kemudian hari. Dari segi teknologi informasi Taman Kanak Kanak X akan meningkatkan dukungan dan pengembangan teknologi informasi yang berguna untuk mengingkatkan pelayanan kepada masyarakat dan orang tua siswa.

\section{b. Strategy}

Pendefinisian dari strategi themes yang didasarkan pada temuan-temuan yang diperoleh dari analisis SWOT yang dilakukan sebelumnya. Berikut adalah pendefinisian strategi themes untuk masing-masing perspektif tersebut.

Perspektif Finansial, yang menjadi persefektif awal dari taman kanak kanak X. Strategi theme untuk persfektif ini adalah pencapaian dan pengembalian pendapatan. Untuk mendukung strategi themes ini perusahaan yang sudah didefinisikan pada persfektif financial, maka dibutuhkan strategi themes yang digunakan pada persfektif customer yaitu meningkatkan kualitas palayanan kepada siswa dan masyarakat dalam menjalankan kegiatan pendidikan. Dan untuk mendukung pencapaian strategi yang telah didefinisikan pada kedua perspektif sebelumnya perusahaan membutuhkan internal business process yang kuat adapun strategi themes untuk internal business proses adalah pencapaian produktivitas proses. Dengan adanya proses yang produktif pad ataman kanak kanak X yang dapat meningkatkan kinerja dari segi keuangan yang akan memberikan dampak yang baik bagi masyarakat dan orangtua siswa. Untuk mendukung pencapaian strategi yang sudah didefinisikan pada persfektif internal bisnis proses dibutuhkan sumber daya terbaik yang ada di taman kanak kanak X. Dan untuk itu dibutuhkan peningkatan komitmen Taman kanak kanak X untuk pengembangan sumber daya, itulah yang kemudian dapat dijadikan strategi untuk perspektif learning and growth yang diterapkan pada Taman kanak kanak X. 


\section{c. Objectives}

Pendefinisian dari objectives taman kanak kanak X akan didasarkan pada strategi themes dan analisis matrik SWOT. Dimana hasil dari analisis matrik SWOT akan dipetakan ke masingmasing perspektif yang ada. Strategi pada perspektif balanced scorecard pada taman kanak kanak X adalah sebagai berikut:

Tabel 2. Empat (4) Perspektif Balanced Scorecard pada Taman Kanak Kanak X

\begin{tabular}{|c|c|c|}
\hline Perspective & Strategic Theme & Strategic Objective \\
\hline Financial & $\begin{array}{l}\text { Pencapaian dan pengembalian } \\
\text { pendapatan }\end{array}$ & $\begin{array}{l}\text { 1. Memberikan harga yang kompetitif } \\
\text { 2. Meningkatkan kepercayaan masyarakat }\end{array}$ \\
\hline Customer & Meningkatkan kualitas pelayanan & $\begin{array}{l}\text { 1. Meningkatkan kualitas dan pelayanan bagi } \\
\text { 2. Masyarakat } \\
\text { paningkatkan mutu dan kualita pelayanan } \\
\text { 3. Meningkatkan kualitas luaran } \\
\text { 4. Meningkatkan sarana dan prasarana }\end{array}$ \\
\hline $\begin{array}{l}\text { Internal Business } \\
\text { Process }\end{array}$ & Pencapaian produktivitas proses & $\begin{array}{l}\text { 1. Meningkatkan kualitas kinerja } \\
\text { 2. Meningkatkan dukungan teknologi } \\
\text { 3. Mermasi } \\
\text { Meningkatkan Jaringan }\end{array}$ \\
\hline Learning and Growth & $\begin{array}{l}\text { Peningkatan komitmen untuk } \\
\text { pengembangan sumber daya }\end{array}$ & $\begin{array}{l}\text { 1. } \\
\text { Meningkatkan kualitas SDM } \\
\text { Mnformasi }\end{array}$ \\
\hline
\end{tabular}

d. Strategy Map

Jika dilihat dari kerangka perspektif yang sudah didefinisikan tersebut, dapat disimpulkan bahwa semua strategi yang ada tidak hanya dikelompokkan kedalam perspektif keuangan saja, tetapi juga dikelompokkan dalam perspektif non keuangan. Strategi yang sudah didefinisikan tersebut akan dirangkum pada sebuat strategi map. Dimana pada strategi map tersebut juga dilihat keterkaitan dari masing-masing strategi objektif yang sudah dikelompokkan pada perspektifnya.

\section{e. Performance Measurement}

Taman Kanak Kanak X perlu untuk melakukan pengukuran terhadap strategy objective yang sudah ditentukan pada tahapan sebelumnya. Tujuan dari penetapan penilaian ini agar pihak perusahaan dapat mengetahui tingkat kesuksesan dari pelaksanaan strategy yang sudah didefinisikan serta memicu semua elemen yang ada di Taman Kanak Kanak X untuk dapat memebrikan kinerja terbaiknya. Pada tabel selanjutnya adalah pendefinisian pengukuran untuk masing-masing strategy objective.

Tabel 3. Performance Measurement Balanced Scorecard pada TK $X$

\begin{tabular}{|c|c|c|c|}
\hline Perspective & Strategic Themes & Strategic Objective & Measurement \\
\hline Financial & $\begin{array}{l}\text { Pencapaiandan } \\
\text { pengembalian } \\
\text { pendapatan }\end{array}$ & $\begin{array}{l}\text { 1. Memberikan harga } \\
\text { yang kompetitif } \\
\text { 2. Meningkatkan } \\
\text { kepercayaan } \\
\text { masyarakat }\end{array}$ & $\begin{array}{l}\text { A. Menghitung ROI (Return of } \\
\text { Investment) } \\
\text { B. Memberikan luaran (Lulusan } \\
\text { Terbaik) terbaik } \\
\text { C. Peningkatan pendapatan dan } \\
\text { keuntungan. }\end{array}$ \\
\hline Customer & $\begin{array}{l}\text { Meningkatkankualitas } \\
\text { palayanan }\end{array}$ & $\begin{array}{l}\text { 1. Meningkatkan kualitas } \\
\text { dan pelayanan bagi } \\
\text { masyarakat } \\
\text { 2. Meningkatkan mutu } \\
\text { dan kualitas pelayanan } \\
\text { pada siswa } \\
\text { 3. Meningkatkan kualitas } \\
\text { luaran }\end{array}$ & $\begin{array}{l}\text { A. Meningkatkan pelayanan } \\
\text { terhadap masyarakat (orang } \\
\text { tua siswa). } \\
\text { B. Memberikan Pengajaran yang } \\
\text { baik dan berkualitas } \\
\text { C. Memberikan loyalitas } \\
\text { terhadap siswa dan orang tua } \\
\text { siswa }\end{array}$ \\
\hline
\end{tabular}




\begin{tabular}{|c|c|c|c|}
\hline & & $\begin{array}{l}\text { 4. Meningkatkan sarana } \\
\text { dan prasarana }\end{array}$ & $\begin{array}{l}\text { D. Meningkatkan prestasi siswa } \\
\text { E. Memberikan sarana dan } \\
\text { prasarana untuk mendukung } \\
\text { pengajan }\end{array}$ \\
\hline $\begin{array}{l}\text { Internal Business } \\
\text { Process }\end{array}$ & $\begin{array}{l}\text { Pencapaian } \\
\text { produktivitas proses }\end{array}$ & $\begin{array}{l}\text { 1. Meningkatkan kualitas } \\
\text { kinerja } \\
\text { 2. Meningkatkan } \\
\text { dukungan teknologi } \\
\text { informasi } \\
\text { 3. Meningkatkan Jaringan }\end{array}$ & $\begin{array}{l}\text { A. Menciptakan lingkungan } \\
\text { kerja dan tempat pengajanran } \\
\text { yang nyaman } \\
\text { B. Membuat aplikasi untuk } \\
\text { mendukung pengajran guru } \\
\text { C. Membuat website sebagai } \\
\text { sarana promosi. } \\
\text { D. Menjalin hubungan yang baik } \\
\text { dengan masyarakat dan siswa. } \\
\text { E. Menciptakan model } \\
\text { pembelajaran yg interkatif }\end{array}$ \\
\hline $\begin{array}{l}\text { Learning and } \\
\text { Growth }\end{array}$ & $\begin{array}{l}\text { Peningkatan komitmen } \\
\text { untuk pengembangan } \\
\text { sumber daya }\end{array}$ & $\begin{array}{ll}\text { 1. } & \text { Meningkatkan kualitas } \\
\text { SDM } \\
\text { 2. } \\
\text { Meningkatkan } \\
\text { dukungan teknologi } \\
\text { informasi }\end{array}$ & $\begin{array}{l}\text { A. Penyelesaian pendefinisian } \\
\text { kompetensi SDM } \\
\text { B. Meningkatkan probabilitas } \\
\text { karyawan } \\
\text { C. Tingkat pertumbuhan usaha } \\
\text { dengan SDM yang sesuai } \\
\text { dengan pendidikan. } \\
\text { D. Meningkatkan perluasan } \\
\text { perusahaan dengan akuisisi }\end{array}$ \\
\hline
\end{tabular}

\section{f. Initiatives}

Initiatives yang didefinisikan untuk taman kanak kanak X didasarkan pada strategi objektif dan measurement pada masing-masing perspektif. Dibawah ini adalah gambar pemetaan (strategy map) dari Balanced Scorecard pada Taman Kanak Kanak X.

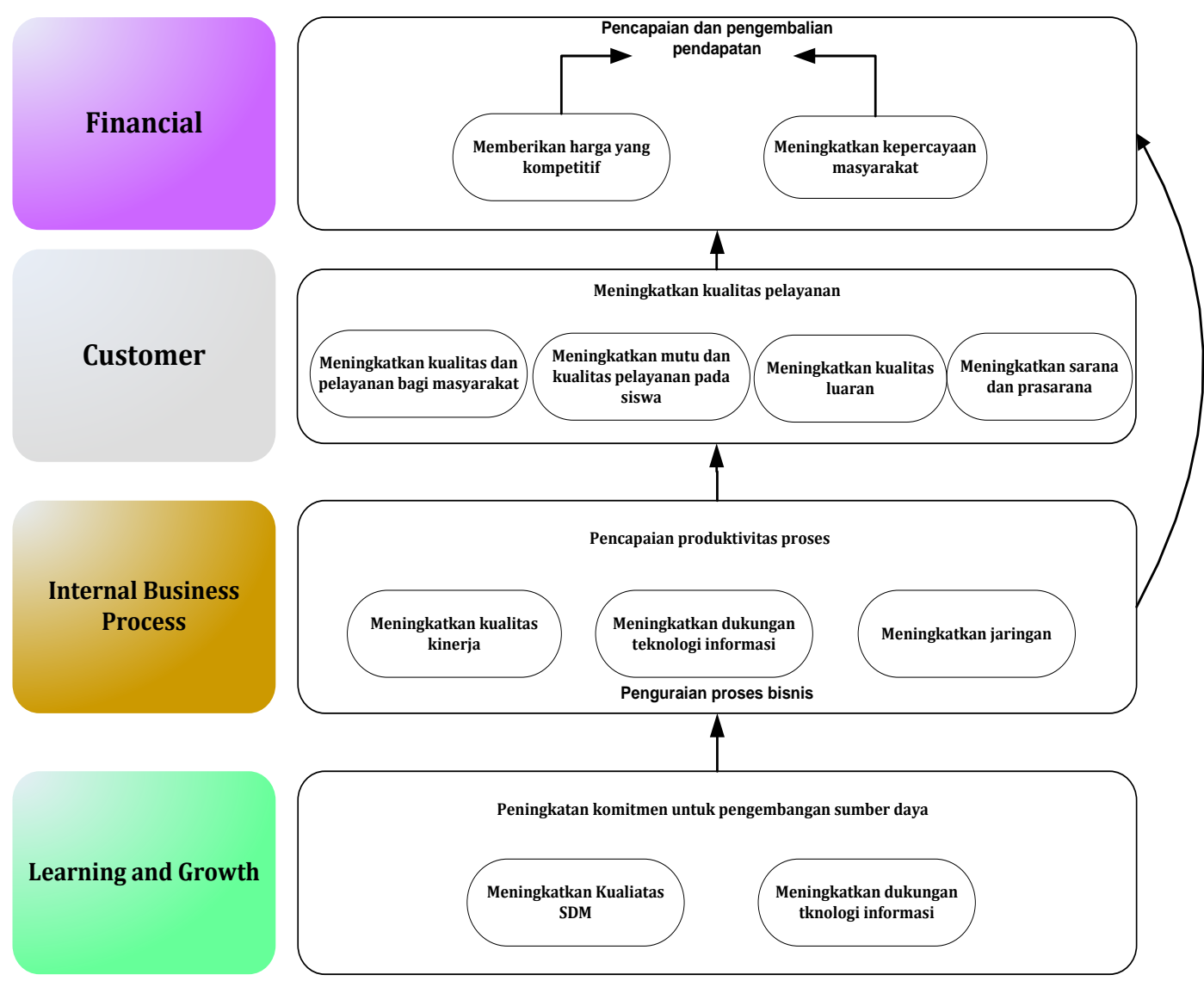

Gambar 3. Pemetaan Balanced Scorecard pada Taman Kanak Kanak X 


\section{Simpulan dan Saran}

\section{Simpulan}

Hasil dari pengolahan data dan analisis yang terhradapat taman kanak kanak $\mathrm{X}$, maka didapatlah simpulan sebagai berikut:

a. Hasil analisis SWOT yang digunakan untuk menganalisis strategi manajemen baik itu internal maupun eksternal yang mendefinisikan mengenai Strength, weakness, opportunities, dan threats yang ada pada taman kanak kanak X, sehingga akan di dapat matriks SWOT yang merepresntasikan semua data hasil analisis SWOT.

b. Hasil analisis Balances Scorecards yang digunakan untuk memetakan sasaran bisnis taman kanak-kanak $\mathrm{x}$ yang akan menjadi tolak ukur, target dan inisiatif untuk kedepannya agar lebih baik lagi yang dapat di lihat dari finansial, costumer, internal business proses dan learning and growth.

\section{Saran}

Berdasarkan hasil penelitian yang telah diuraikan, maka penelitian ini dapat dikembang lagi dengan menggunakan metode yang lain.

\section{Daftar Pustaka}

Jogiyanto. (2005). Sistem Informasi Strategik: Untuk keunggulan kompetitif. Yogyakarta: ANDI.

Kaplan, Norton. (1996). The Balanced Score:Translating Strategy Into Action. Harvad: Business Press.

Dewi, M., dan Alusyanti, P. (2014). Pemetaan Strategic Management Dengan Balanced Scorecard Pada PT. A. Jurnal Orbith, Vol.10 No.1 60-66.

Bergeron, B.(2003). Essensials of knowledge Management. New York: John Wiley \& Sons.

Winardi. (2000). Kepemimpinan dalam Manajemen. Jakarta: Rineka Cipta.

Ward, John, dan Peppard, Joe. (2002). Strategic Planning for Information Systems. England: John Wiley and Sons Ltd. 